\title{
ETIKA DAN KODE ETIK PROFESI HUKUM
}

\author{
B. Arief Sidharta \\ email: bernardariefsidharta@yahoo.com
}

\begin{abstract}
One of the most important aspects of society is a well functioning professionals scientifical development and application are carried out by professionals and modern society cannot exit without both. The same can be said in regard to the legal profession, in this paper represented by judges and advocates. Profession therefore should be regarded an institutional framework, in which the development and teaching of sciences and humanities and its practical application in the field of spiritual service, medicine, technology, law, information and education are to be realized. Practice howerver tell a different story, and professionals perform their work within a certain socio-political field. This paper discusses the inter-relationship between professionals and their respective ethical rights and duties.
\end{abstract}

Keywords:

profession, the legal profession, ethics, code of ethics of the legal profession.

\begin{abstract}
Abstrak
Banyak aspek-aspek terpenting dalam tatanan masyarakat untuk sebagian terbesar sangat tergantung pada berfungsinya profesi-profesi dengan baik. Kegiatan pengembangan ilmu dan penerapan ilmu dilaksanakan dalam suatu konteks profesional. Hasil-hasil dari berfungsinya profesi-profesi sangat erat terjalin dalam tatanan masyarakat modern. Demikian pula yang terjadi dalam profesi hukum, yang dalam tulisan ini diwakili oleh Hakim dan Advokat. Profesi adalah suatu kerangka institusional yang di dalamnya sejumlah fungsi kemasyarakatan yang paling penting dijalankan, terutama pengembangan serta pengajaran ilmu dan humaniora dan penerapan praktikalnya dalam bidang-bidang pelayanan rokhani, kedokteran, teknologi, hukum, informasi dan pendidikan. Dalam perwujudannya profesi tersebut ternyata tidak selalu berlangsung dengan sendirinya sebagai konsekuensi dari keyakinan pada pentingnya fungsi-fungsi itu, melainkan sangat dipengaruhi oleh berinteraksinya berbagai kekuatan kemasyarakatan. Tulisan ini akan membahas hal tersebut dikaitkan dengan pengertian profesi, tugas dan etik serta kode etik profesi hukum.
\end{abstract}

Kata kunci:

profesi, profesi hukum, etika, kode etik profesi hukum.

"Nos scimus quia lex bona est, modo quis ea utatur legitime." (Kita mengetahui bahwa undang-undang itu adalah baik sepanjang orang menggunakannya secara sah.), Francis Bacon.

" ... the lawyers and the judges ... (are) the spokesmen of the fundamental values of the community ..." , Charles E. Wyzanski Jr., 1951.

\section{Pendahuluan}

Seorang sosiolog Amerika, tokoh mazhab Fungsionalisme Struktural, Talcott Parsons dalam karyanya berjudul "The Professions and Social Structure" 
pada tahun 1939 yang kemudian dimuat dalam buku kumpulan karangan berjudul "ESSAYS IN SOCIOLOGICAL THEORY" (1964), berdasarkan studi komparatif terhadap struktur-struktur masyarakat dari sejumlah peradaban yang terpenting menyatakan bahwa "the professions occupy a position of importance in our society which is, .... unique in history." 1 Banyak dari aspek-aspek terpenting dari tatanan masyarakat untuk sebagian terbesar sangat tergantung pada berfungsinya profesi-profesi dengan baik. Kegiatan pengembangan ilmu dan penerapan ilmu dilaksanakan dalam suatu konteks profesional. Hasil-hasil dari berfungsinya profesi-profesi sangat erat terjalin dalam tatanan masyarakat modern. Profesi-profesi dalam sistem sosial okupasi (pekerjaan) pada masyarakat modern menempati kedudukan yang sangat strategis, sehingga Parsons mengatakan bahwa "it is difficult to imagine how it could get along without basic structural changes if they were seriously impaired."2

Pengamatan menunjukkan bahwa di Amerika Serikat, pengembanan profesi kedokteran sering menyebabkan bekas pasien atau keluarga pasien menggugat dokter ke pengadilan dengan tuntutan ganti rugi yang cukup "aduhai". Hal ini menyebabkan para dokter di Amerika Serikat berusaha melindungi diri dengan menutup kontrak asuransi dengan premi yang semakin meningkat, dan menjalankan "defensive medicine", yang kesemuanya pada akhirnya mengakibatkan biaya pelayanan kesehatan menjadi sangat mahal. Pengamatan ini menunjukkan bahwa pengembanan profesi kedokteran tengah mengalami gangguan yang cukup serius. Di Indonesia, hal yang sama tampak dari berkembangnya minat terhadap aspek yuridis dari hubungan antara dokter dan pasien, yang antara lain didorong oleh terjadinya konspirasi antara dokter, apotik dan pabrik obat melalui "sales". Dalam bidang hukum, gejala merosotnya pengembanan profesi hukum tampak dari munculnya istilah "Mafia Peradilan", dan orang mulai merasa bahwa sebaiknya untuk menyelesaikan suatu kasus

\footnotetext{
1 Talcot Parson, Essays in Sociological Theory, Revised Edition, The Free Press, New York, 1964, hlm. 35.

2 Id.
} 
sedapat mungkin jangan ke pengadilan dengan bantuan pengemban profesi hukum (advokat). Apa artinya jika dikatakan bahwa profesi mengalami kemerosotan (seriously impaired)? Apa ukurannya untuk menilai demikian? Jawabnya adalah jika etika dan kode etik profesi tidak dipatuhi oleh sebagian besar para pengembannya. Tetapi, apa etika dan kode etik profesi itu, dan mengapa profesi memerlukan etika dan kode etik profesi? Jawabannya akan tergantung pada pengertian kita tentang apa profesi itu. Tulisan ini akan membahas tentang kaitan antara etika dan kode etik profesi hukum.

\section{Pengertian Profesi}

Perkataan profesi dan profesional sudah sering digunakan dan mempunyai beberapa arti. Dalam percakapan sehari-hari, perkataan profesi diartikan sebagai pekerjaan (tetap) untuk memperoleh nafkah (Belanda: baan; Inggris: job atau occupation), yang legal maupun yang tidak. Jadi, profesi diartikan sebagai setiap pekerjaan untuk memperoleh uang. Dalam arti yang lebih teknis, profesi diartikan sebagai setiap kegiatan tetap tertentu untuk memperoleh nafkah yang dilaksanakan secara berkeakhlian yang berkaitan dengan cara berkarya dan hasil karya yang bermutu tinggi dengan menerima bayaran yang tinggi. Keakhlian tersebut diperoleh melalui proses pengalaman, belajar pada lembaga pendidikan (tinggi) tertentu, latihan secara intensif, atau kombinasi dari semuanya itu. Dalam kaitan pengertian ini, sering dibedakan pengertian profesional dan profesionalisme sebagai lawan dari amatir dan amatirisme, misalnya dalam dunia olah-raga, yang sering juga dikaitkan pada pengertian pekerjaan tetap sebagai lawan dari pekerjaan sambilan.

Ignas Kleden dalam sebuah artikel berjudul "KAUM PROFESIONAL DAN PEMBAGIAN KERJA INTELEKTUAL,"3 memberikan arti yang agak berbeda pada istilah "profesional". Dalam artikel itu ia mengemukakan:

"... seorang profesional memberikan nilai tukar kepada pengetahuan (exchange value of knowledge). Di tangan profesional pengetahuan dan

3 Baca : Kompas, 12 Mei 1986. 
ilmu berubah wujudnya menjadi komoditi yang bisa dipertukarkan dalam suatu transaksi jual-beli. ... seorang profesional menerjemahkan pengetahuan ... menjadi unsur pasar ... menjadi penguasaan komersial terhadap pengetahuan... membuat pengetahuan menjadi jasa yang dapat dipertukarkan. ... yang menyibukkan seorang profesional adalah terjual-tidaknya suatu pengetahuan.... Masalah yang muncul dalam profesionalisme adalah masalah yang juga muncul dalam setiap tukar menukar, yaitu, apakah "barang" yang diperjual-belikan itu cukup terjamin mutunya atau tidak. Dalam hal seorang profesional, apakah jasa yang dijualnya itu betul merupakan pengetahuan yang sudah cukup teruji secara ilmiah..... Seorang profesional yang baik dan berhasil adalah orang yang sanggup menjual dengan harga tinggi suatu pengetahuan yang teruji mutunya. Seorang profesional yang gagal hanya sanggup menjual dengan harga rendah suatu pengetahuan yang teruji mutunya. Tetapi "the betrayal of the professionals" akan terjadi kalau dia menjual dengan harga tinggi suatu pengetahuan yang sama sekali belum teruji secara ilmiah, atau bahkan sudah terbukti sebagai pengetahuan yang tak terjamin mutunya. ..."

Demikianlah kutipan yang agak "in extenso" dari artikel Ignas Kleden untuk menghindari tafsiran subjektif. Dalam uraian Ignas Kleden tentang pengertian profesional tersirat (atau dapat disimpulkan) pengertian profesi sebagai pekerjaan tetap dalam bidang tertentu yang dijalankan secara berkeahlian berdasarkan penguasaan ilmu, jadi dengan menerapkan ilmu, tertentu sehingga mampu menawarkan dan memberikan jasa yang bermutu tinggi yang sudah teruji secara ilmiah, dengan bayaran tinggi sesuai dengan mutu karya dan hasilnya yang ditawarkan itu. Pandangan ini tampaknya cocok untuk masyarakat yang tatanan ekonominya menganut kapitalisme.

Berbeda dengan pandangan Ignas Kleden tadi, Roscoe Pound, filsuf hukum tokoh aliran Sociological Jurisprudence yang terkenal dengan gagasannya tentang hukum sebagai "a tool for social engineering", dalam bukunya mengatakan bahwa perkataan profesi "refers to a group of men pursuing a learned art as a common calling in the spirit of a public service, no less a public service because it may incidentally be a means of livelihood."4

\footnotetext{
${ }^{4}$ Roscoe Pond, The Lawyers from Antiquity to Modern Times, 1953.
} 
Pandangan Roscoe Pound tentang pengertian profesi pada dasarnya sejalan dengan pandangan Talcott Parsons. Berdasarkan artikel yang telah disebut di atas, dan artikel (entri) berjudul "PROFESSIONS" yang dimuat dalam "INTERNATIONAL ENCYCLOPEDIA OF THE SOSCIAL SCIENCES" Vol. 12 (1972),5 pandangan Talcott Parsons tentang pengertian profesi dapat dikemukakan sebagai berikut ini. Di dalam "PROFESSIONS", Parsons mengemukakan bahwa "profesional" bukanlah kapitalis, pekerja (buruh), administrator pemerintah, birokrat, ataupun petani pemilik tanah. Batas lingkup profesi sebagai institusi sosial tidaklah jelas dan juga tidak tegar. Dalam kenyataan terdapat kelompok-kelompok marginal yang status keprofesionalannya ekuivokal. Namun, kriteria inti untuk mengkualifikasi suatu okupasi sebagai suatu profesi cukup jelas. Pertama, profesi mensyaratkan pendidikan teknis yang formal dilengkapi dengan cara pengujian yang terinstitusionalisasikan, baik mengenai adekuasi dari pendidikannya maupun mengenai kompetensi dari orang-orang hasil didikkannya. Pengujian para calon pengemban profesi terutama diarahkan pada unsur intelektual, jadi sangat mengutamakan valuasi rasionalitas kognitif yang diterapkan pada bidang khusus tertentu. Ini berarti bahwa profesi adalah aplikasi ilmu tertentu pada bidang kehidupan yang perwujudannya akan terjamin lebih baik jika menerapkan ilmu tersebut. Dengan perkataan lain, pengemban profesi dituntut menguasai ilmu yang bersangkutan. Kedua, penguasaan tradisi kultural dalam menggunakan keahlian tertentu serta keterampilan dalam penggunaan tradisi tersebut. Ini berarti bahwa dalam lingkungan suatu profesi berlaku suatu sistem nilai yang berfungsi sebagai standar normatif yang harus menjadi kerangka orientasi dalam pengembanan profesi yang bersangkutan. Ketiga, kompleks okupasi (sistem sosial pekerjaan) tersebut memiliki sejumlah sarana institusional untuk menjamin bahwa kompetensi tersebut akan digunakan dengan cara-cara yang secara sosial bertanggung-jawab. Wujudnya adalah berupa organisasi profesi, etika dan kode etik profesi dengan prosedur penegakannya, serta cara

5 David L. Sills (ed.), International Encyclopedia of the Social Sciences, Vol. 9 \& 12, Macmillan \& the 
rekrutasi pengemban profesi. Berdasarkan kriteria inti tadi, maka secara umum dapat dikatakan bahwa profesi itu menunjuk pada kompleks okupasional yang terorganisasikan seputar disiplin-disiplin intelektual (yang meliputi humaniora, ilmu-ilmu alam dan ilmu-ilmu sosial), dan sistem-sistem kultural (nilai-nilai) yang diolah oleh dan di dalam kompleks okupasi tersebut. ${ }^{6}$

Di dalam "PROFESSIONS AND SOCIAL STRUCTURE", Parsons mengemukakan ciri-ciri khusus profesi sebagai suatu sistem okupasional. ${ }^{7}$ Pertama, "disinterestedness" atau tidak berorientasi pada pamrih. Masyarakat memandang pengemban profesi tidak sebagai orang yang terlibat dalam usaha untuk mencari keuntungan bagi diri sendiri, melainkan lebih memandangnya sebagai orang yang mewujudkan pelayanan kepada pasien atau kliennya, atau pada nilai-nilai impersonal seperti kemajuan ilmu.

Sikap demikian adalah nilai yang merupakan standar normatif bagi pengemban profesi dalam mengemban profesinya. Ciri "disinterestedness" ini tidak begitu saja berkaitan dengan motif "egoistik" dan "altruistik" yang memotivasi perilaku sosial orang. Kedua, "rasionalitas". Di atas sudah dikemukakan bahwa profesi menunjuk pada suatu sistem okupasional yang perwujudannya dilaksanakan dengan menerapkan ilmu tertentu. Salah satu ciri dominan dari ilmu adalah rasionalitasnya dalam arti sebagai lawan dari tradisionalisme. Penelitian ilmiah berorientasi pada standar normatif tertentu, dan salah satu di antaranya adalah "kebenaran objektif". Dalam penerapan ilmu, maka rasionalitas menunjuk pada usaha mencari yang terbaik, cara yang paling efisien dalam menjalankan fungsi, dan yang terbaik itu adalah yang bertumpu pada pertimbangan ilmiah dalam melaksanakan fungsi. Ketiga, "spesifisitas fungsional". Di dalam masyarakat, para profesional menjalankan atau memiliki kewibawaan (otoritas). Otoritas profesional ini memiliki struktur sosiologikal yang khas. Ia bertumpu pada "kompetensi teknikal" yang superior dari pengemban profesi. Hal ini

Free Press, New York-London, 1972.

6 Id.

7 Id. 
dimungkinkan, karena medan dari otoritas profesional itu terbatas pada satu lingkungan keahlian teknis khusus tertentu. Otoritas profesional ditandai oleh spesifisitas fungsi. Kompetensi teknikal, sebagai salah satu ciri khas dari status dan peranan profesi, selalu terbatas pada satu bidang pengetahuan dan keakhlian tertentu. Spesifisitas ini adalah unsur esensial pada pola profesional. Seorang profesional dianggap "suatu otoritas" (orang yang memiliki otoritas) hanya dalam bidangnya. Keempat, "universalisme" dalam pengertian objektivitas sebagai lawan dari "partikularisme" (subjektivitas). Yang dimaksud di sini dengan universalisme adalah bahwa landasan pertimbangan profesional dalam pengambilan keputusan didasarkan pada "apa yang menjadi masalahnya" dan tidak pada "siapanya" atau keuntungan apa yang dapat diperoleh bagi dirinya.

Pandangan fungsionalistik dari Talcott Parsons tentang profesi itu kemudian oleh Dietrich Rueschemeyer secara ringkas dipaparkan dalam karya berjudul "Lawyers and Doctors : A Comparison of Two Professions."8 sebagai berikut ini, profesi adalah pekerjaan pelayanan yang menerapkan seperangkat pengetahuan sistematis (ilmu) pada masalah-masalah yang sangat relevan bagi nilai-nilai utama dari masyarakat. Kompetensi berkeilmuan berkualitas tinggi yang dimiliki para pengemban profesi itu menciptakan masalah khusus tentang pengawasan masyarakat terhadap mereka: awam tidak mampu menilai karya profesional, dan dalam banyak hal bahkan mereka tidak dapat menetapkan sendiri sasaran konkret bagi karya profesional yang diperlukannya. Ini berarti bahwa pengawasan formal oleh birokrasi pemerintahan dan pengawasan informal oleh konsumen terhadap karya profesional, praktis tidak berarti banyak.

Di lain pihak, dirasakan bahwa adanya pengawasan terhadap karya profesional itu sangat diperlukan mengingat nilai-nilai dan kepentingan-kepentingan yang dipertaruhkan berkenaan dengan pengembanan karya profesional. Dilema ini dipecahkan dengan memberikan tekanan kuat pada pengendalian diri secara individual pada pihak pengemban profesi, yang

8 Vilhelm Aubert, Sociology of Law, Penguin, 1973, hlm. 267. 
dilandaskan pada suatu proses sosialisasi yang panjang yang didisain untuk membangun kompetensi teknikal yang diperlukan dan untuk menegakkan komitmen yang kuat pada nilai-nilai dan norma-norma yang menjiwai tugas para pengemban profesi.

Nilai-nilai dan norma-norma itu kemudian diinstitusionalisasikan dalam struktur dan kultur dari profesi yang bersangkutan. Dengan demikian, pengendalian diri secara individual itu diperkuat dengan pengawasan formal dan informal oleh komunitas sejawat. Sebagai imbalan atas kesediaan untuk mematuhi "orientasi kolektivitas" yang dikendalikan sendiri itu, masyarakat memberikan privilese dan keuntungan seperti pendapatan (honor) yang tinggi dan prestise, dan melindungi otonomi profesi terhadap pengawasan dan campur tangan awam.

Bertumpu pada pandangan Roscoe Pound, Talcott Parsons dan Dietrich Rueschemeyer, dapatlah kita rumuskan pengertian profesi sebagai berikut: profesi adalah pekerjaan tetap berupa karya pelayanan (service occupation) yang pelaksanaannya dijalankan dengan menerapkan pengetahuan ilmiah dalam bidang tertentu yang pengembanannya dihayati sebagai suatu panggilan hidup dan terikat pada etika umum dan etika khusus (yakni etika profesi) yang bersumber pada semangat pengabdian terhadap sesama manusia demi kepentingan umum, serta berakar dalam penghormatan terhadap martabat manusia. Dalam pengertian tadi, maka profesi itu adalah suatu fungsi kemasyarakatan tertentu yang perwujudannya mensyaratkan penerapan (aplikasi) disiplin ilmu tertentu.

Sistem okupasi (sistem sosial pekerjaan) yang dapat dikualifikasi sebagai profesi dalam pengertian tadi sekurang-kurangnya ada lima, yakni keimaman (ulama), kedokteran, hukum, jurnalistik, dan pendidikan. Kelima bidang kegiatan kemasyarakatan itu langsung berkaitan dengan pemenuhan kebutuhan dasar bagi eksistensi manusia yang bermartabat manusiawi dalam keutuhannya dan dengan nilai-nilai kemanusiaan yang fundamental, yakni relasi dengan yang transenden (ke-Illahi-an), kesehatan, kepastian hukum yang berkeadilan, informasi yang 
relevan, dan sosialisasi yang dinamis-kreatif (upaya sistematikal memanusiakan manusia).

\section{Etika Profesi, Kode Etik dan Landasannya}

Pengemban profesi adalah orang yang memiliki keahlian yang berkeilmuan dalam bidang tertentu. Karena itu, ia secara mandiri mampu memenuhi kebutuhan warga masyarakat yang memerlukan pelayanan dalam bidang yang memerlukan keakhlian berkeilmuan itu. Pengemban profesi yang bersangkutan sendiri yang memutuskan tentang apa yang harus dilakukannya dalam melaksanakan tindakan pengembanan profesionalnya. Ia secara pribadi bertanggung-jawab atas mutu pelayanan jasa yang dijalankannya. Karena itu, hakikat hubungan antara pengemban profesi dan pasien atau kliennya adalah hubungan personal, yakni hubungan antar subyek pendukung nilai.

Hubungan personal yang demikian itu tadi adalah hubungan horisontal antara dua pihak yang secara formal-yuridis kedudukannya sama. Walaupun demikian, sesungguhnya dalam substansi hubungan antara pengemban profesi dan pasien atau klien itu secara sosio-psikologikal terdapat ketidak-seimbangan.

Dalam pengembanan profesinya, seorang pengemban profesi memiliki dan menjalankan otoritas profesional terhadap pasien atau kliennya, yakni otoritas yang bertumpu pada kompetensi teknikalnya yang superior. Pasien atau klien tidak memiliki kompetensi teknikal atau tidak berada dalam posisi untuk dapat menilai secara objektif pelaksanaan kompetensi teknikal pengemban profesi yang diminta pelayanan profesionalnya.

Karena itu, jika pasien atau klien mendatangi/menghubungi pengemban profesi untuk meminta pelayanan profesionalnya, maka pada dasarnya pasien atau klien tersebut tidak mempunyai pilihan lain kecuali memberikan kepercayaan kepada pengemban profesi tersebut bahwa ia akan memberikan pelayanan profesionalnya secara bermutu dan bermartabat.

Uraian tadi menunjukkan bahwa hubungan horisontal antara pengemban profesi dan pasien atau kliennya juga bersifat suatu hubungan kepercayaan. Ini 
berarti bahwa pasien atau klien yang meminta pelayanan jasa profesional, mendatangi pengemban profesi yang bersangkutan dengan kepercayaan penuh bahwa pengemban profesi itu tidak akan menyalah-gunakan situasinya, bahwa pengemban profesi itu secara bermartabat akan mengerahkan pengetahuan dan keakhlian berkeilmuannya dalam menjalankan pelayanan jasa profesionalnya. Karena merupakan suatu fungsi kemasyarakatan yang langsung berkaitan dengan nilai dasar yang menentukan derajat perwujudan martabat manusia, maka sesungguhnya pengembanan profesi atau pelayanan profesional itu memerlukan pengawasan masyarakat.

Tetapi, masyarakat pada umumnya, yang bukan pengemban profesi yang bersangkutan, tidak memiliki kompetensi teknikal untuk dapat menilai dan melakukan pengawasan yang efektif terhadap pengembanan profesi. Juga birokrasi pemerintahan sulit melaksanakan pengawasan dan pengendalian kemasyarakatan (kontrol sosial) terhadap pelayanan profesional secara efektif. Daya jangkau kontrol sosial birokrasi pemerintahan dengan bersaranakan kaidah-kaidah hukum sangat terbatas, baik karena sifat personal pada hubungan antara pengemban profesi dan klien atau pasiennya, maupun karena, seperti dikatakan Mochtar Kusumaatmadja, "hukum, baik hukum pidana maupun hukum administrasi negara, mengatur tindakan-tindakan manusia yang nyata ('de uiterlijke gedragingen en handelingen van de mens') dan harus mendasarkan pengaturannya (termasuk pembuktian dan sanksinya) pada tindakan-tindakan nyata itu. ${ }^{\prime \prime}$

Ini berarti bahwa pengemban profesi memiliki kekuasaan dan menjalankan kewibawaan tertentu terhadap pasien atau kliennya. Demikianlah, Mochtar Kusumaatmadja mengatakan "... bahwa setiap profesi menempatkan ahli yang bersangkutan dalam suatu keadaan yang istimewa, baik karena kekuasaan yang luar biasa yang dipercayakan kepadanya (seperti dalam hal hakim dan jaksa)

9 Mochtar Kusumaatmadja, Pembaharuan Pendidikan hukum dan Pembinaan Profesi, Majalah Hukum dan Pengetahuan Masyarakat "PADJADJARAN", Jilid V, No. 3-4, 1974, hlm. 18. 
maupun karena nasib daripada orang yang berkepentingan dipercayakan kepadanya (dalam hal pembela)."10

Karena itu, sehubungan dengan nilai-nilai dan kepentingan yang terlibat di dalamnya, maka pengembanan profesi itu menuntut agar pengemban profesi dalam melaksanakan pelayanan profesionalnya dijiwai sikap etis tertentu. Sikap etis yang dituntut menjiwai pengembanan profesi itulah yang disebut etika profesi.

Kieser, dalam tulisan berjudul "ETIKA PROFESI",11 mengatakan bahwa etika profesi sebagai sikap hidup adalah kesanggupan untuk memenuhi kebutuhan pelayanan profesional dari pasien atau klien dengan keterlibatan dan keakhlian sebagai pelayanan dalam rangka kewajiban masyarakat sebagai keseluruhan terhadap para anggota masyarakat yang membutuhkannya dengan disertai refleksi yang seksama.

Berdasarkan pengertian tadi, terdapat kaidah-kaidah pokok etika profesi sebagai berikut. Pertama, profesi harus dipandang (dan dihayati) sebagai suatu pelayanan, sehingga karena itu, maka sifat tanpa pamrih (disinterestedness) menjadi ciri khas dalam mengemban profesi. Yang dimaksud dengan "tanpa pamrih" di sini adalah bahwa pertimbangan yang menentukan dalam pengambilan keputusan adalah kepentingan pasien atau klien dan kepentingan umum, dan bukan kepentingan sendiri (pengemban profesi). Jika sifat tanpa pamrih itu diabaikan, maka pengembanan profesi akan mengarah pada pemanfaatan (yang dapat menjurus pada penyalah-gunaan) sesama manusia yang sedang mengalami kesulitan atau kesusahan. Kedua, pelayanan profesional dalam mendahulukan kepentingan pasien atau klien mengacu pada kepentingan atau nilai-nilai luhur sebagai norma kritik yang memotivasi sikap dan tindakan. Ketiga, pengembanan profesi harus selalu berorientasi pada masyarakat sebagai keseluruhan. Keempat, agar persaingan dalam pelayanan berlangsung secara sehat sehingga dapat menjamin mutu dan peningkatan mutu pengembanan

10 Id, hlm. 17. 
profesi, maka pengembanan profesi harus bersemangatkan solidaritas antar-sesama rekan seprofesi. ${ }^{12}$

Hubungan personal-horisontal yang bersifat kepercayaan itu berakar dalam hubungan personal-vertikal antara Tuhan dan manusia pengemban profesi. Hubungan personal-vertikal antara Tuhan dan manusia berintikan cinta-kasih. Cinta-kasih terhadap Tuhan mengharuskan perwujudan cinta-kasih tersebut terhadap sesama manusia. Jadi, cinta-kasih terhadap Tuhan harus menjiwai hubungan personal-horisontal.

Dengan cinta-kasih sebagai landasan hubungan personal-horisontal, maka cinta-kasih itu juga akan memotivasi untuk menghayati profesi sebagai fungsi kemasyarakatan, dan memotivasi untuk mewujudkan etika profesi sebagai realisasi sikap hidup dalam mengemban profesi. Dengan demikian, maka pengembanan profesi memperoleh landasan religius. Karena itu, bagi seorang yang beriman, maka mengemban profesi sebagai fungsi kemasyarakatan adalah juga mewujudkan iman dengan tindakan nyata.

Etika profesi adalah sikap etis sebagai bagian integral dari sikap hidup dalam menjalani kehidupan sebagai pengemban profesi. Hanya pengemban profesi yang bersangkutan sendiri yang dapat atau yang paling mengetahui tentang apakah perilakunya dalam mengemban profesi memenuhi tuntutan etika profesinya atau tidak. Karena tidak memiliki kompetensi teknikal, maka awam tidak dapat menilai hal itu. Ini berarti, kepatuhan pada etika profesi akan sangat tergantung pada akhlak pengemban profesi yang bersangkutan.

Di samping itu, pengembanan profesi sering dihadapkan pada situasi yang menimbulkan masalah yang pelik untuk menentukan perilaku apa yang memenuhi tuntutan etika profesi. Sedangkan perilaku dalam pengembanan profesi dapat membawa akibat (negatif) yang jauh terhadap pasien atau klien. Kenyataan yang dikemukakan tadi menunjukkan bahwa kalangan pengemban profesi itu sendiri membutuhkab adanya pedoman obyektif yang lebih konkret

11 B. Kieser, Etika Profesi, Majalah BASIS, No. XXXV/5, 1986. 
bagi perilaku profesionalnya. Karena itu, dari dalam lingkungan para pengemban profesi itu sendiri dimunculkan seperangkat kaidah perilaku sebagai pedoman yang harus dipatuhi dalam mengemban profesi. Perangkat kaidah itulah yang disebut kode etik profesi (biasa disingkat: kode etik), yang dapat tertulis maupun tidak tertulis.

Pada masa kini, kode etik itu pada umumnya berbentuk tertulis yang ditetapkan secara formal oleh organisasi profesi yang bersangkutan. Pada dasarnya, kode etik itu bertujuan untuk di satu pihak menjaga martabat profesi yang bersangkutan, dan di lain pihak untuk melindungi pasien atau klien (warga masyarakat) dari penyalahgunaan keakhlian dan/atau otoritas profesional. Pada dasarnya kode etik termasuk kelompok kaidah moral positif.

\section{Profesi Hukum}

Profesi hukum berkaitan dengan masalah mewujudkan dan memelihara ketertiban yang berkeadilan di dalam kehidupan bermasyarakat. Ketertiban yang berkeadilan itu adalah kebutuhan dasar manusia, karena hanya dalam situasi demikian manusia dapat menjalani kehidupannya secara wajar, yakni sesuai dengan martabat kemanusiaanya.

Keadilan adalah nilai dan keutamaan yang paling luhur dan merupakan unsur esensial dari martabat manusia. Oliver W. Holmes Jr. dalam pidato di hadapan Suffolk Bar Association mengatakan bahwa: "of all secular professions this has the highest standardt" (dari semua profesi sekular, profesi ini memiliki standar yang paling tinggi). ${ }^{13}$ Hukum, kaidah-kaidah hukum positif, kesadaran hukum, kesadaran etis dan keadilan bersumber pada penghormatan terhadap martabat manusia. Penghormatan terhadap martabat manusia adalah titik tolak atau landasan bertumpunya serta tujuan akhir dari hukum.

Sebagai sarana untuk mewujudkan ketertiban yang berkeadilan, hukum diwujudkan dalam pelbagai kaidah perilaku kemasyarakatan yang disebut kaidah

12 Id. 
hukum. Keseluruhan kaidah hukum positif yang berlaku dalam suatu masyarakat tersusun dalam suatu sistem yang disebut tata hukum. Ada dan berfungsinya tata hukum dengan kaidah-kaidah hukumnya serta penegakannya adalah produk dari perjuangan manusia dalam upaya mengatasi pelbagai masalah kehidupan, termasuk menanggulangi dan mengarahkan kecenderungan-kecenderungan primitif yang negatif agar menjadi positif dan mengaktualisasikan atau memproduktifkan kecenderungan-kecenderungan positif yang ada dalam diri manusia. Dalam perjuangan itu manusia berusaha memahami, mengolah dan mengakomodasikan secara kreatif pelbagai kenyataan kemasyarakatan pada nilai-nilai yang dianut dan mengekspresikannya ke dalam sistem penataan perilaku dan kehidupan bersama dalam wujud kaidah-kaidah hukum, sehingga bermanfaat bagi perlindungan martabat manusia sesuai dengan tingkat perkembangan peradaban yang sudah tercapai. ${ }^{14}$ Dapat dikatakan bahwa dalam dinamika kesejarahan umat manusia, hukum dan tata hukumnya termasuk salah satu faktor yang sangat penting dalam proses pengadaban dan penghalusan budi pekerti umat manusia. Kualitas kehidupan hukum dan tata hukum suatu masyarakat mencerminkan tingkat keadaban dan akhlak atau situasi kultural masyarakat yang bersangkutan. Demikianlah, Oliver Wendell Holmes Jr. dalam "The Path of the Law" mengatakan bahwa "The law is the witness and external deposit of our moral life. Its history is the history of the moral development of the race."

Penyelenggaraan dan penegakan ketertiban yang berkeadilan dalam kehidupan bersama sebagai suatu kebutuhan dasar manusia agar kehidupan manusia tetap bermartabat adalah suatu fungsi kemasyarakatan. Pada tingkat peradaban yang sudah majemuk, fungsi kemasyarakatan penyelenggaraan dan penegakan ketertiban yang berkeadilan itu dalam kehidupan sehari-hari diwujudkan oleh profesi hukum. Dalam makalah berjudul "Notities over de juridische opleiding.", H.F.M. Crombag mengklasifikasi peran kemasyarakatan

13 Julius Marke, The Holmes Reader, Oceana's Docket Books, New York, 1955, hlm. 61. 
profesi hukum itu ke dalam empat bidang karya hukum, yakni: penyelesaian konflik secara formal (peradilan), pencegahan konflik (legal-drafting, legal advice), penyelesaian konflik secara informal, dan penerapan hukum di luar konflik. ${ }^{15}$

Pada masa kini, yang termasuk profesi hukum yang secara khas mewujudkan bidang karya hukum adalah jabatan-jabatan hakim, advokat dan notaris. Jabatan manapun yang diembannya, seorang pengemban profesi hukum dalam menjalankan fungsinya harus selalu mengacu pada tujuan hukum untuk memberikan pengayoman kepada setiap manusia dengan mewujudkan ketertiban yang berkeadilan, yang bertumpu pada penghormatan martabat manusia.

\section{Hakim (the spokemen of the fundamental values of the community)}

Dalam dinamika kehidupan sehari-hari tidak jarang terjadi konflik kepentingan antarwarga masyarakat. Untuk dapat secara teratur menyelesaikan konflik kepentingan dengan baik demi terpeliharanya ketertiban yang berkedamaian di dalam masyarakat, diperlukan adanya institusi (kelembagaan) khusus yang mampu memberikan penyelesaian secara tidak memihak (imparsial) dan berlandaskan patokan-patokan yang berlaku secara objektif. Demikianlah, melalui proses yang panjang terbentuklah institusi peradilan lengkap dengan aturan-aturan prosedural dan jabatan-jabatan yang berkaitan, yakni hakim, advokat dan jaksa.

Wewenang pokok dari lembaga peradilan adalah melakukan tindakan pemeriksaan, penilaian dan penetapan nilai perilaku manusia tertentu serta menentukan nilai suatu situasi konkret dan menyelesaikan persoalan (konflik) yang ditimbulkannya secara imparsial berdasarkan hukum (patokan objektif). Wewenang itulah yang disebut kewenangan (kekuasaan) kehakiman atau kewenangan judisial. Pengambilan keputusan dalam mewujudkan kewenangan kehakiman tersebut, dalam kenyataan konkret, dilaksanakan oleh pejabat

14 Lon L. Fuller, Anatomy of the Law, A Pelican Book, 1971, hlm. 9.

15 H.F.M. Crombag, Notities over de juridische opleiding. 
lembaga peradilan yang dinamakan hakim. Lembaga peradilannya disebut pengadilan.

Pada dasarnya, tugas hakim adalah memberikan keputusan atas setiap perkara (konflik) yang dihadapkan kepadanya. Artinya, hakim bertugas untuk menetapkan hubungan hukum, nilai hukum dari perilaku serta kedudukan hukum para pihak yang terlibat dalam situasi yang dihadapkan kepadanya, atau, sebagaimana dikatakan oleh John Marshall dalam kasus Marbury v. Madison: "to say what the law is", menyatakan apa hukumnya bagi situasi konkret tertentu. ${ }^{16}$

Ini berarti, menyelesaikan konflik berdasarkan hukum, asas-asas kebenaran dan keadilan. Sehubungan dengan fungsinya itu tadi, maka hakim haruslah menjadi "the living oracle of the law" (Blackstone), dan sebagai demikian ia seperti dikatakan Wyzanski juga harus berperan sebagai juru-bicara nilai-nilai fundamental dari masyarakat atau "the spokesmen of the fundamental values of the community". ${ }^{17}$

Hal yang dikemukakan tadi hanya mungkin terwujud, jika para hakim dalam menjalankan tugasnya selalu mengacu pada penghormatan terhadap martabat manusia. Dengan demikian tugas pokok hakim adalah selain memberikan penyelesaian definitif terhadap sengketa yang dihadapkan kepadanya dan pembentukan hukum baru yang sesuai, juga melaksanakan pendidikan.

Agar dapat menyelesaikan masalah atau konflik yang dihadapkan kepadanya secara imparsial berdasarkan hukum yang berlaku, maka dalam proses pengambilan keputusan, para hakim harus mandiri dan bebas dari pengaruh pihak yang mana pun, termasuk dari pemerintah. Dalam mengambil keputusan, para hakim hanya terikat pada fakta-fakta yang relevan dan kaidah hukum yang menjadi atau dijadikan landasan yuridis keputusannya. Tetapi, penentuan fakta-fakta mana yang termasuk fakta-fakta yang relevan dan pilihan kaidah

\footnotetext{
16 Richard D. Heffner, A Documentary History of the United States, A Mentor Book, New York, 1962, hlm. 81.

17 Charles E. Wyazanki Jr, The New Meaning of Justice, Bantam Book, 1966, hlm. 5.
} 
hukum yang mana yang akan dijadikan landasan untuk menyelesaikan kasus yang dihadapinya diputuskan oleh hakim yang bersangkutan itu sendiri. Dengan demikian, jelas bahwa hakim atau para hakim memiliki "kekuasaan" yang besar terhadap para pihak (yustisiabel) berkenaan dengan masalah atau konflik yang dihadapkan kepada hakim atau para hakim tersebut. ${ }^{18}$

Namun, dengan demikian berarti pula bahwa para hakim dalam menjalankan tugasnya sepenuhnya memikul tanggung-jawab yang besar dan harus menyadari tanggung-jawabnya itu. Sebab, keputusan hakim dapat membawa akibat yang sangat jauh pada kehidupan para yustisiabel dan/atau orang-orang lain yang terkena oleh jangkauan keputusan tersebut; keputusan hakim tersebut mengubah nasib orang-orang tertentu. Keputusan hakim yang tidak adil bahkan dapat mengakibatkan penderitaan lahir dan batin yang dapat membekas dalam batin para yustisiabel yang bersangkutan sepanjang perjalanan hidupnya.

Dalam suatu negara hukum, hakim itu adalah pejabat negara yang tugas utamanya adalah memberikan penyelesaian definitif terhadap konflik atau sengketa antar-warga masyarakat atau antara warga masyarakat dan pemerintah yang dihadapkan kepadanya secara imparsial, obyektif, adil dan manusiawi.

Agar proses penyelesaian konflik itu dapat dilakukan secara imparsial, maka dalam menjalankan tugasnya hakim harus memiliki kebebasan dari campur tangan siapapun, termasuk dari pemerintah, yang disebut kebebasan kekuasaan kehakiman, dan ia tidak boleh memiliki hubungan tertentu dengan para pihak yang dapat menimbulkan konflik kepentingan (conflict of interest), misalnya hubungan darah atau hubungan kekeluargaan yang dekat.

Tuntutan imparsialitas dan obyektivitas itu mengimplikasikan kekuasaan kehakiman yang bebas. Selain itu, untuk menjaga imparsialitasnya (ketidakberpihakannya), hakim harus bersifat pasif dalam arti bahwa ia harus menunggu sampai suatu sengketa dihadapkan kepadanya untuk memperoleh

18 Mochtar, Ibid, hlm. 17. 
penyelesaian, dan tidak boleh mengambil prakarsa sendiri untuk menyelesaikan suatu sengketa. Sebab, jika hakim bertindak aktif untuk atas prakarsa sendiri menetapkan bahwa suatu peristiwa atau suatu keadaan atau suatu hal adalah sebuah sengketa yang harus diselesaikannya, maka ia akan sudah berprasangka dan proses penyelesaiannya akan bias karena akan dipengaruhi oleh prasangkanya itu, dan putusannya akan menjadi tidak imparsial, tidak obyektif dan tidak adil lagi. (menghadapkan kasus tersebut kepada hakim), demi penegakan hukum.

Tepatnya, tugas hakim itu adalah untuk mewujudkan keadilan secara berkepastian dengan setepat mungkin menerapkan kaidah hukum positif yang berlaku, jadi mewujudkan keadilan dengan menerapkan kaidah hukum positif. Atau, dengan kata lain, menerapkan hukum positif secara adil atau demi untuk mewujudkan keadilan.

Agar putusannya obyektif, maka putusan yang diambilnya untuk memberikan penyelesaian atas sengketa yang dihadapkan kepadanya harus selalu berdasarkan fakta-fakta yang terbukti dalam pemeriksaan di persidangan pengadilan, dan berdasarkan patokan-patokan obyektif yang berlaku umum, yakni kaidah hukum positif yang berlaku sebagaimana yang dirumuskan dalam perundang-undangan yang ruang lingkup penerapannya mencakup fakta-fakta tersebut tadi dengan secara eksplisit menyebutkan ketentuan perundangundangan yang dijadikan dasar bagi putusannya, atau kaidah hukum positif yang berwujud hukum kebiasaan (hukum tidak tertulis).

Di Indonesia, hal ini pada saat sekarang ditegaskan dalam Pasal 50 ayat 1 Undang-undang No. 48 Tahun 2009 tentang Kekuasaan Kehakiman, yang menetapkan:

"Segala putusan Pengadilan selain harus memuat alasan-alasan dan dasar-dasar putusan tersebut, memuat pula pasal tertentu dari peraturan yang bersangkutan atau sumber hukum tak tertulis yang dijadikan dasar untuk mengadili." 
Fakta-fakta dan aturan hukum positif yang dijadikan dasar untuk putusannya harus dikemukakan secara eksplisit dalam pertimbanganpertimbangan dari putusan tersebut. Dalam bahasa hukum, pertimbangan yang memuat alasan-alasan faktual dan dasar hukum dari putusan itu disebut motivering.

Agar proses penyelesaian sengketa lewat peradilan dapat berlangsung secara imparsial dan obyektif, maka proses tersebut harus dilakukan melalui prosedur yang dapat menjamin imparsialitas dan obyektivitas dan dibakukan dalam seperangkat kaidah-kaidah hukum yang disebut Hukum Acara atau Hukum Prosedural. Dalam kaitan dengan upaya untuk menjamin imparsialitas proses penyelesaian konflik itu, maka Hukum Acara tersebut harus memuat ketentuanketentuan dan asas-asas tentang pembagian beban pembuktian, audi et alteram partem (mendengar semua pihak terkait), dan kewajiban memberikan motivering kehakiman. Dalam sebuah negara hukum, perangkat kaidah-kaidah hukum acara itu dirumuskan secara tertulis dalam perundang-undangan yang harus diterapkan secara ketat. Penyimpangan terhadap aturan prosedural ini pada dasarnya harus dipandang sebagai kolusi yang melawan hukum. Karena itu, jika terjadi suatu keadaan yang memaksa harus dilakukan penyimpangan, demi terwujudnya keadilan misalnya, maka penyimpangan ini harus dapat dipertanggung-jawabkan yang diungkapkan secara eksplisit dalam pertimbangan (motivering) dari putusan hakim terkait, sehingga dari berbagai segi penyimpangan tersebut secara rasional dapat diterima dan dibenarkan.

Berlandaskan uraian tadi, hakim harus memiliki sikap etis atau etika profesi hakim yang berintikan: takwa kepada Tuhan Yang Maha Esa, jujur, adil, bijaksana, imparsial (tidak memihak), sopan, sabar, memegang teguh rahasia jabatan, dan solidaritas sejati. Sikap etis tadi harus tercermin dalam perilaku sehari-hari yang bebas dari cela. Hanya dengan bersikap etis demikian saja, para hakim akan mampu memelihara martabat dan kewibawaan profesi hakim. Demikianlah, Francis Bacon dalam "ESSAYS OR COUNSELS CIVIL AND MORAL: OF JUDICATURE." mengatakan: 
"Judges ought to be more learned than witty, more reverend than plausible, and more advised than confident. Above all things, integrity is their portion and proper virtue. Cursed (saith the law) is he that removeth the landmark. The mislayer of a mere-stone is to blame. But it is the unjust judge that is the capital remover of the landmarks, when he defineth amiss of lands and property. One foul sentence doth more hurt than many foul examples. For these do but corrupt the stream, the other corrupteth the fountain. So saith Solomon, 'Fons turbatus, et vena corrupta, est justus cadens in causa sua coram adversario.' (A righteous man losing his case is like a troubled fountain or a corrupt spring.) ... there is no worse torture than the torture of laws."19

Di Indonesia pada masa kini etika profesi itu telah dijabarkan ke dalam Kode Kehormatan Hakim yang ditetapkan oleh Rapat Kerja Para Ketua Pengadilan Tinggi dan Pengadilan Negeri di bawah pimpinan Mahkamah Agung pada tahun 1966, yang kemudian diteguhkan dan dimantapkan dalam Musyawarah Nasional Ikatan Hakim Indonesia (IKAHI) ke IX pada tanggal 23 Maret 1988. Kemudian, Kode Kehormatan Hakim itu diganti dengan Keputusan Bersama Ketua Mahkamah Agung Republik Indonesia dan Ketua Komisi Yudisial Republik Indonesia, Nomor 047/KMA/SKB/IV/2009 dan Nomor 02/SKB/P.KY/IV/2009, tentang Kode Etik Dan Pedoman Perilaku Hakim.

\section{Advokat}

Pengacara (advokat) adalah orang yang dalam proses peradilan bertugas untuk menampilkan fakta-fakta dari kejadian yang menimbulkan sengketa terkait selengkap mungkin, dan tentu saja yang mendukung kepentingan kliennya, termasuk aturan-aturan hukum yang dipandang relevan dan interpretasinya. Kesemuanya itu dikemas dalam suatu argumentasi rasional yang dibangun untuk mencapai suatu putusan hukum yang adil-manusiawi dari sudut pihak kliennya. Karena kedua belah pihak memperoleh (dan harus diberikan) kesempatan yang sama untuk mengemukakan fakta-fakta dan aspek hukumnya dari pihak kliennya

19 Louis Blom-Cooper, The Language of the Law, The Bodley head, London, 1965, hlm. 3-4. 
masing-masing yang dikemas dalam suatu argumentasi hukum, maka dapat diharapkan bahwa hakim akan memperoleh fakta-fakta yang lengkap dan utuh.

Dari sini tampak jelas bahwa tugas utama yang sesungguhnya dari para advokat dalam suatu proses peradilan adalah untuk membantu hakim atau pengadilan dalam upaya mencapai suatu putusan hukum sebagai penyelesaian definitif terhadap sengketa yang dihadapkan ke pengadilan secara adil-manusiawi dalam kerangka sistem hukum positif yang berlaku dalam negara yang bersangkutan. Jadi, tugas advokat itu bukan hanya semata-mata untuk memenangkan kliennya saja, melainkan sebagai penegak hukum bertugas juga untuk mewujudkan keadilan sejati di dalam masyarakat.

Pada dasarnya tugas pokok advokat adalah memberikan nasihat hukum untuk menjauhkan klien dari konflik, dan mengajukan atau membela kepentingan klien di pengadilan (menyelesaikan konflik secara formal). Dalam berperkara di pengadilan, peran utama seorang advokat adalah mengajukan berbagai fakta dan pertimbangan yang relevan dari sudut pihak kliennya untuk memungkinkan hakim menetapkan keputusan yang seadilnya.

Profesi advokat pada dasarnya dapat berperan pada semua bidang karya hukum yang dimaksud oleh Crombag. Dalam mengemban profesinya itu, advokat juga harus selalu mengacu pada usaha mewujudkan ketertiban dan kepastian hukum yang berkeadilan. Karena itu, pada dasarnya etika profesi hakim berlaku juga bagi para advokat. Secara etis, para advokat berkewajiban untuk menegakkan asas-asas hukum dan martabat manusia.

Dalam kata pengantar pada bukunya yang berjudul "COURTROOM", sebuah biografi seorang advokat yang kemudian menjadi hakim terkenal bernama Samuel S. Leibowitz, Quentin Reynolds menulis: ${ }^{20}$

"DETECTIVE STORY", karya pemenang Hadiah Pulitzer bernama Sidney Kingsley, adalah salah sebuah "hits" pada musim teater tahun 1949. Dalam cerita sandiwara itu, Kingsley menciptakan tokoh Endicott Sims, seorang advokat yang mengkhususkan diri dalam bidang perkara-perkara pidana. Seorang ditektif yang sadis, Letnan

20 Quentin Reynolds, Courtroom, Popular Library. 
James McLeod, merasa terganggu oleh Sims karena advokat itu memprotes McLeod yang telah menganiaya seorang tersangka yang menjadi klien Sims. Tersangka yang dianiaya itu hampir mati. Sims mengatakan kepada ditektif itu bahwa ia beruntung karena ia tidak menghadapi tuduhan pembunuhan berat (murder charge).

Tokoh "Sims" mengekspresikan filsafat hukum dari seorang advokat yang memiliki komitmen pada etika profesi. Leibowitz tidak merasa bahwa ia, jaksa, atau masyarakat umum mempunyai hak untuk memprahakimi seorang tersangka, betapa pun ia tampaknya bersalah. Leibowitz dengan sepenuh hatinya meyakini asas hukum yang menyatakan bahwa seorang tertuduh harus dianggap tidak bersalah." Kutipan tadi mengungkapkan sikap etis seorang advokat dalam mengemban profesinya secara bermartabat.

Musyawarah Nasional Advokat Indonesia I pada tanggal 10 November 1985 di Jakarta telah menetapkan Kode Etik Advokat Indonesia. Pada saat sekarang, kode etik advokat yang berlaku adalah kode etik yang ditetapkan oleh Komite Kerja Advokat Indonesia pada tanggal 23 Mei 2002.

\section{Praktisi Hukum Perlu Memiliki Pemahaman tentang Filsafat Hukum yang Memadai}

Para pengemban profesi hukum, baik para hakim maupun para advokat dan juga para notaris, untuk dapat melaksanakan tugasnya mengemban profesinya sebagai hakim atau sebagai advokat harus memiliki dan menguasai pengetahuan ilmu hukum, sejarah hukum, sosiologi hukum dan filsafat hukum yang memadai.

Dengan menerapkan dan menggunakan pengetahuan dalam disiplindisiplin ilmiah tersebut, maka para hakim dan advokat tersebut akan mampu secara tepat menyaring fakta-fakta yang relevan dari yang tidak relevan, menyeleksi aturan-aturan hukum yang tepat yang terkait pada fakta-fakta yang telah disaringnya, menginterpretasi aturan-aturan hukum terkait untuk mendistilasi (menarik keluar dan menampilkan ke permukaan atau 
mengeksplisitkan) kaidah hukum yang tercantum secara implisit di dalam aturan hukum itu secara kontekstual, untuk kemudian membangun suatu argumentasi hukum untuk memaparkan sejelas mungkin apa peristiwa hukum yang sesungguhnya telah terjadi di antara para pihak, dan berdasarkan itu merumuskan setajam mungkin apa yang menjadi pertanyaan hukumnya yang harus dijawab untuk dapat menyelesaikan sengketa hukum yang telah terjadi di antara para pihak.

Dengan pemahaman yang memadai tentang filsafat hukum, maka para hakim dan advokat (dan juga jaksa) akan mampu melakukan "moral reading" (dipinjam dari Ronald Dworkin) terhadap perundang-undangan yang berlaku ketika melakukan seleksi terhadap perundang-undangan untuk menemukan aturan hukum yang relevan untuk kasus yang tengah ditangani, dan juga melakukan "moral reading" terhadap aturan-aturan hukum yang telah dipilihnya untuk menemukan kaidah hukum yang tercantum di dalamnya yang akan diterapkan pada kasus terkait, dan dengan itu maka tujuan yang ingin diwujudkan dengan kaidah hukum itu akan dapat ditemukan.

Dengan cara demikian maka penerapan aturan hukum tersebut dapat dilakukan secara bertujuan, sehingga dapat menjadi fungsional terhadap tujuan kemasyarakatan dari hukum pada umumnya, dan penerapan hukum yang demikian akan menjadi sungguh-sungguh adil dan "membumi".

Demikianlah, jika para pengemban profesi hukum itu, para hakim dan para advokat, melaksanakan tugasnya masing-masing seperti digambarkan di atas tadi, maka pengembanan profesi hukum itu akan dapat menghadirkan profesi hukum yang sungguh-sungguh layak untuk disebut "officium nobile" (profesi bermartabat, status profession). Untuk itu maka para pengemban profesi hukum, baik hakim maupun advokat, dituntut untuk memiliki ahlak yang tinggi, yang menghormati dan memiliki komitmen yang sungguh-sungguh untuk melaksanakan etika profesinya masing-masing. 


\section{Kedudukan Etika Profesi Dan Kode Etik Dalam Hukum}

Dalam keadaan normal, secara umum dapat dikatakan bahwa kehidupan masyarakat berlangsung secara relatif tertib (tidak terjadi situasi anomia atau "bellum omnium contra omnes"). Ketertiban dalam masyarakat itu disebabkan oleh adanya dan bekerjanya berbagai nilai dan kaidah.

Berdasarkan isi, karakter dan tujuannya, kaidah-kaidah yang bekerja dalam masyarakat itu dapat kita bedakan ke dalam pengelompokan berikut: kaidah budi nurani, kaidah moral positif, kaidah kesopanan, kaidah agama, dan kaidah hukum. Semua kaidah itu berakar atau timbul dari dalam akal-budi dan nurani manusia.

Dalam ranah hukum dapat dibedakan dua kelompok kaidah hukum, yakni kelompak kaidah hukum mandiri (kaidah hukum otonom) dan kelompok kaidah hukum tidak mandiri (kaidah hukum tidak otonom). Produk kaidah-kaidah yang dibentuk oleh komunitas-komunitas yang memiliki otonomi dan otonominya itu diakui atau diberikan oleh hukum adalah hukum tidak mandiri yang demikian itu dan diperlakukan sebagai bagian dari hukum positif. Contohnya: "hospital by laws" yang yang dibentuk oleh rumah sakit mengikat sebagai hukum positif bagi rumah sakit yang bersangkutan, karena bertumpu pada perundang-undangan di bidang kesehatan. Statuta di sebuah perguruan tinggi juga termasuk hukum tidak mandiri yang demikian berdasarkan perundang-undangan di bidang pendidikan, khususnya pendidikan tinggi.

Di Indonesia, secara umum, dapat dikatakan bahwa hukum mengakui dan melindungi otonomi keberadaan profesi tertentu dengan etika profesi dan kode etiknya. Beberapa di antaranya, yakni pengakuan terhadap otonomi profesi tersebut, sudah dirumuskan secara eksplisit dalam perundang-undangan, misalnya Undang-undang tentang Praktik Kedokteran, Undang-undang tentang Advokat, Undang-undang tentang Notaris, Undang-undang tentang Rumah Sakit, Undang-undang tentang Pers, dsb. 


\section{Aspek Hukum Pengembanan Profesi}

\section{Makna Yuridis Hubungan Pengemban Profesi Dan Klien}

Dipandang dari sudut hukum, hubungan hukum antara pengemban profesi (selanjutnya disebut profesional) dan orang yang meminta atau membutuhkan pelayanan profesionalnya (selanjutnya disebut klien) adalah suatu perikatan. Perikatan itu dapat dan pada umumnya ditimbulkan oleh perjanjian (kontrak). Dengan terbentuknya perikatan, maka timbullah hak-hak dan kewajibankewajiban pada para pihak terkait.

Perjanjian antara profesional dan klien dapat disebut kontrak profesional, yakni kontrak melakukan tindakan profesional. Dalam perjanjian ini prestasinya adalah melakukan suatu jasa berupa tindakan pertolongan profesional dari pihak profesional dan pembayaran honorarium dari pihak klien. Perjanjian profesional ini pada dasarnya termasuk perjanjian yang menghasilkan perikatan ikhtiar. Sehubungan dengan itu, profesional berkewajiban melakukan upaya semaksimal mungkin dengan mengerahkan keahlian berkeilmuan secara seksama sesuai dengan standar dan prosedur standar yang berlaku berdasarkan tingkat perkembangan ilmu yang bersangkutan. Dalam hal-hal tertentu, hubungan profesional-klien termasuk perikatan hasil-karya, misalnya pada profesi arsitektur, profesi dokter bedah.

\section{Standar Profesional}

Karena hubungan professional-klien itu pada dasarnya adalah suatu perikatan ikhtiar, maka secara yuridis dipenuhi atau tidak dipenuhinya prestasi dari pihak profesional tidak terutama ditentukan oleh hasilnya (misalnya kesembuhan dalam profesi kedokteran), melainkan oleh cara kerjanya: sejauh mana dokter telah berupaya semaksimal mungkin dan secermat apa dokter telah menjalani prosedur-baku (standard operating procedure) yang berlaku? Jadi, secara umum dapat dikatakan bahwa dalam intinya kontrak terapeutik (dalam profesi kedokteran) itu menimbulkan kewajiban, tidak untuk menyembuhkan yang sakit, melainkan untuk memberikan perawatan medik (melakukan tindakan 
medik) dengan keterlibatan secara seksama dan penuh kesungguhan, serta dengan tidak mengabaikan situasi eksepsional, sesuai dengan tingkat perkembangan ilmu dan teknologi kedokteran yang telah dicapai (Cour de Cassation Perancis, Michiels van Kessenich-Hogendam, Roscam Abbing).

Di sini tampak jelas bahwa secara yuridis, rekam medik, yang kini diatur dalam Permenkes No. 749a/MENKES/PER/XII/1989, sangat penting dan dapat sangat menentukan. Dalam pasal 14 butir (b) dinyatakan bahwa rekam medik dapat digunakan sebagai bahan pembuktian dalam perkara hukum. Tentang ukuran untuk mengkaji sejauh mana suatu tindakan medik telah memenuhi syarat yang dituntut bagi pelaksanaan profesi kedokteran, dalam kepustakaan telah dimunculkan pengertian-pengertian untuk menyatakan ukuran tersebut, antara lain: ikhtiar sejawat rata-rata, kemampuan sejawat rata-rata, sejawat yang baik, sejawat yang berpengalaman, kehati-hatian normal, dsb. Berdasarkan berbagai pengertian itu, dengan mengingat pula bahwa situasi riil yang di dalamnya tindakan medik atau tindakan profesional itu dilakukan harus ikut dipertimbangkan, maka dapat disimpulkan bahwa unsur normatif pada pengkajian suatu tindakan profesional pada dasarnya adalah "upaya sejawat yang bertindak secara rasional dalam konteks wilayah aplikasi bidang keilmuan yang bersangkutan".

"Upaya sejawat yang bertindak secara rasional" mencakup dua aspek, yakni aspek subyektif dan aspek obyektif. Aspek subyektif meliputi: sikap batin profesional, perhatian dan keprihatinannya terhadap pasien/klien yang dihadapi, kesediaannya untuk sungguh-sungguh mendalami masalah yang dihadapi pasien dan kesungguhan untuk memecahkannya. Aspek subyektif ini, perhatian dan kesungguhan, harus terungkap dalam sikap dan perilakunya. Aspek obyektifnya mencakup keahlian (kompetensi) dari profesional, pengetahuan dan keterampilan (kemahiran) pada umumnya, serta peralatan yang tersedia. Kedua aspek tersebut bersama-sama mewujudkan keseksamaan dalam melaksanakan pengembanan profesi. Aspek subyektif bersifat konstan dan tidak dipengaruhi oleh lingkungan. 
Dalam keadaan apapun seorang profesional harus melaksanakan pekerjaannya (menjalankan tindakan profesional) dengan penuh perhatian dan kesungguhan. Aspek obyektif (syarat kompetensi) dapat dipengaruhi oleh faktor lingkungan. Dengan demikian, maka unsur perhatian dan kesungguhan diukur berdasarkan perhatian dan kesungguhan dari sejawat yang bertindak rasional.

Sedangkan unsur kompetensi diukur berdasarkan kompetensi dari sejawat yang bertindak secara rasional dalam keadaan (kondisi) yang sama. Situasi khusus dalam suatu kasus konkret dapat mempengaruhi pertanggung-gugatan profesional. Syarat keseksamaan membawa beberapa konsekuensi, antara lain:

a. Hal menentukan apakah suatu tindakan profesional tertentu harus dilakukan atau tidak adalah tanggung-jawab dari profesional terkait. Masalah akan timbul jika klien/pasien menolak tindakan profesional, dan klien/pasien berdasarkan pengakuan atas integritas jasmani dan rohaninya (otonomi) memang berhak untuk menolak tindakan profesional tertentu.

b. Profesional wajib menolak melakukan tindakan profesional tertentu, jika menurut keyakinannya tindakan tersebut memerlukan pengetahuan, keahlian dan pengalaman khusus, yang tidak dimilikinya. Dalam hal itu, profesional tersebut harus mengirim klien/pasien kepada spesialis terkait, yang implementasinya tergantung pada situasi riil.

c. Profesional harus mengikuti perkembangan ilmu yang bersangkutan, sehingga pelaksanaan tugasnya dapat selalu sesuai dengan tingkat perkembangan ilmu yang telah dicapai.

Berdasarkan uraian di atas, malpraktik adalah kealpaan (negligence), ketidakahlian (inkompetensi), dan ketidak-seksamaan (lack of conscientiousness) dalam melaksanakan pengembanan profesi. Malpraktik yang mengakibatkan hasil yang merugikan pada klien/pasien dapat menimbulkan gugatan secara perdata. Ada dua dasar hukum yang utama bagi pertanggung-gugatan perdata ini, yakni: pertanggung-gugatan kontraktual (wanprestasi) dan pertanggung-gugatan berdasarkan perbuatan melanggar hukum (onrechtmatige daad). 


\section{Penutup}

Uraian di atas menggambarkan profesi dan profesi hukum dalam bentuk ideal. Dalam kenyataan dapat kita temukan penyimpangan-penyimpangan atau pengkhususan. Dalam kenyataan konkret hampir tidak ada sesuatu yang hadir dalam bentuk idealnya. Namun, jika penyimpangan-penyimpangan cukup jauh dan mencakup banyak aspek serta meluas sekali, maka mungkin kita dapat berbicara tentang krisis atau perubahan fundamental dengan segala akibat kemasyarakatannya. Uraian ini justru dimulai dengan menunjukkan gejala-gejala yang memperlihatkan kemungkinan adanya krisis dalam dunia profesi kita yang mungkin mencakup semua profesi.

Dari apa yang telah dikemukakan, dapat dikatakan bahwa profesi adalah suatu kerangka institusional yang di dalamnya sejumlah fungsi kemasyarakatan yang paling penting dijalankan, terutama pengembangan serta pengajaran ilmu dan humaniora dan penerapan praktikalnya dalam bidang-bidang pelayanan rokhani, kedokteran, teknologi, hukum, informasi dan pendidikan. Bidang-bidang tersebut secara langsung berkaitan dengan nilai-nilai yang fundamental bagi perwujudan martabat manusia dalam kenyataan riil. Dalam perwujudannya ternyata tidak selalu berlangsung dengan sendirinya sebagai konsekuensi dari keyakinan pada pentingnya fungsi-fungsi itu, melainkan sangat dipengaruhi oleh berinteraksinya berbagai kekuatan kemasyarakatan. Ini berarti bahwa perwujudannya secara nyata memerlukan upaya yang memadukan berbagai kekuatan tersebut, yakni perlu upaya secara sadar dengan dukungan kemauan yang kuat untuk menegakkan etika profesi dan kode etik profesi. Untuk itu perlu diupayakan agar profesi-profesi mampu mempertahankan otonominya lewat organisasi profesi yang kemandiriannya diakui dan dihormati oleh penguasa politik, serta didukung oleh kurikulum, proses dan metode pendidikan yang juga memuat upaya untuk secara sistematis menumbuhkan sikap etis yang sesuai kepada peserta didiknya. 
Yang disebut terakhir ini sangat penting, sebab, demikian dikatakan oleh Mochtar Kusumaatmadja, "pendidikan ketrampilan teknis tanpa disertai pendidikan tanggung jawab professional dan etika adalah berbahaya".21

\section{Daftar Pustaka:}

Buku:

Aubert, Vilhelm, Sociology of Law, Penguin, 1973.

Blom-Cooper, Louis, The Language of the law, The Bodley Head, London, 1965.

Binziad Kadafi, cs: Advokat Indonesia mencari Legitimasi: Studi tentang tanggung jawab Profesi Hukum di Indonesia, Pusat Studi \& Kebijakan Indonesia,

E.J. Kanter, Etika Profesi Hukum, Sinar Grafika, Jakarta, 2001.

Evaristus Sumaryono, Etika Profesi Hukum, Norma-norma bagi penegak hukum, Kanisius, Yogyakarta, 1995.

Fuller, Lon L., Anatomy of the Law, A Pelican Book, 1971.

Heffner, Richard D., A Documentary History of the United States, A Mentor Book, New York, 1962.

Koehn, Daryl, Landasan Etika Profesi, Kanisius, Yogyakarta, 2000.

Marke, Julius, The Holmes Reader, Oceana's Docket Books, New York, 1955.

Loth-Gaakeer, Ethiek en het juridisch beroep, oleh M.A. Loth dan A.M.P. Gaakeer, Boom Juridisch uitgevers, Den Haag, 2007.

Luhut M.P. Pangaribuan, Advokat dan Contempt of Court, Djambatan, Jakarta, 2006. Parsons, Talcott, Essays In Sociological Theory. Revised Edition, The Free Press, New York, 1964.

Pound, Roscoe, The Lawyers from Antiquity of Modern Times.

Reynolds, Quentin, Courtroom, Popular Library.

Shidarta, Moralitas Profesi Hukum, Refika Aditama, Bandung, 2006.

Suhrawardi K. Lubis, Etika Profesi Hukum, Sinar Grafika, Jakarta, 1994.

Wyzanski Jr., Charles E., The New Meaning of Justice, Bantam Book, 1966.

Yudha Pandu, Klien \& Advokat, Indonesia Legal Center Publishing, Jakarta, 2004.

Non Buku:

Kieser, B., Etika Profesi, Majalah BASIS, No. XXXV/5. 1986.

Kleden, Ignas, Kaum Profesional dan Pembagian Kerja Intelektual, Harian Umum KOMPAS, 12 Mei 1986.

Kusumaatmadja, Mochtar, Pembaharuan Pendidikan Hukum dan Pembinaan Profesi., Majalah Hukum Dan Pengetahuan Masyarakat "PADJADJARAN", jilid V, No. 3-4, 1974.

21 Mochtar, Id, pada hlm. 17. 
Sills, David L. (ed.), International Encyclopedia of the Social Sciences, Volume 9 dan 12, Macmillan \& The Free Press, New York-London, 1972.

Wirjanto, Soemarno P., Ilmu Hukum Profesi, Fakultas Hukum Universitas Katolik Parahyangan, 1980.

Simposium Pembaharuan Pendidikan Hukum dan Pembinaan Profesi Hukum, 1975. 